\title{
Anthropometric evaluations and assessment of school furniture design in Nigeria: A case study of secondary schools in rural area of Odeda, Nigeria
}

\author{
Adekunle Ibrahim Musa ${ }^{a}$
}

${ }^{a}$ Mechanical Engineering Department, Moshood Abiola Polytechnic, PMB 2210, Abeokuta, Nigeria

\begin{tabular}{|c|c|}
\hline A R T I C L E I N F O & A B S T RACT \\
\hline $\begin{array}{l}\text { Article history: } \\
\text { Received 20 January } 2011 \\
\text { Accepted 25 March } 2011 \\
\text { Available online } \\
\text { 26 March } 2011 \\
\text { Keywords: } \\
\text { Anthropometric dimensions } \\
\text { Schoolchildren } \\
\text { Classroom furniture } \\
\text { Ergonomic }\end{array}$ & $\begin{array}{l}\text { This study was carried out on } 621 \text { schoolboys with age range of } 12-17 \text { years in Junior and } \\
\text { Senior Secondary Schools in Odeda area of Odeda local government in Ogun State, Nigeria. } \\
\text { Different anthropometric data were collected from these boys. It was observed from the results } \\
\text { that all anthropometric dimensions of the school children increase with their age. Moreover, } \\
\text { there exists a little difference between mean values of different anthropometric dimensions } \\
\text { between the boys of } 12-13 \text { years ( } 2.9 \% \text { to } 8.8 \%), 14-15 \text { years }(1.3 \% \text { to } 9.9 \%) \text {, and } 16-17 \text { years } \\
\text { (1.4\% to } 5.5 \%) \text {. But the said differences become much higher ( } 16.2 \% \text { to } 42.4 \%) \text { when the same } \\
\text { were compared between the children of } 12 \text { years and } 17 \text { years. Therefore, it can be said that the } \\
\text { design of furniture for the children of } 12 \text { years will not match the children of } 17 \text { years. If single } \\
\text { furniture is designed by considering dimensions of the children from } 12 \text { years to } 17 \text { years, it will } \\
\text { also not suit the children of all age groups. Therefore, in the present investigation, all the } \\
\text { students have been divided into three combined age groups, e.g., } 12-13 \text { years, } 14-15 \text { years, and } \\
16-17 \text { years, and the percentile values }\left(5^{\text {th }}, 50^{\text {th }} \text { and } 95^{\text {th }}\right) \text { of anthropometric measures, which } \\
\text { will be helpful for designing of the classroom furniture. }\end{array}$ \\
\hline
\end{tabular}

(C) 2011 Growing Science Ltd. All rights reserved

\section{Introduction}

School is a home away from home for the children, with a purpose to facilitate their learning activities. Children spend a considerable part of their daily life (between 5 and 7 hours per day) at school. Children spend about $80 \%$ of their school time in the classroom performing various activities like reading, writing, drawing and other related activities, which requires them to sit continuously for long hours (Savanur et al., 2004). In a research work Hira (1980) concluded that four types of activities namely, listening, writing, calculating and miscellaneous were being carried out by the students in a classroom. So, children spend a major time on the chair and desk during school hours. Hence, it is necessary that the school furniture should fit the requirements of school children (Savanur et al., 2004, Gouvali \& Boudolos, 2006). Therefore, the school furniture should be made on the basis of anthropometric dimensions of the user (school children) of different age groups. There are some primary considerations in workstation design. It should be recognized that the body measurements;

* Corresponding author. Tel: +234(8035050573)

E-mail: kunlemusa@yahoo.com (A. I. Musa) 
anthropometric data, of a population group should be specific to the type of workplace (Nag, 1996, Castellucci et al., 2010). To obtain fitness between man-machine components, the maximum number of user population should use a workplace. It strives to accommodate 95 percent of the user population, in general. The dimensions of the small people establish the reach dimensions, e.g., If the shorter people can reach the objects located on higher shelves, virtually everyone else can also do the job. On the other hand, when the taller people can fit in a confined area, like aisle, tunnel area, emergency exit, all others can also be accommodated. Moreover, design of this furniture should be different for male and female student, as Jeong and Park (1990) observed differences in the requirements of furniture dimensions for boys and girls. The existing school furniture, i.e., chairs and desks may not be suitable for the children as these are designed without considering their body dimensional requirements. It has been reflected from many studies that there is a mismatch between the classroom furniture dimensions and the anthropometric dimensions of the school children. In a study, Chaudhary et al. (2004) showed that the school furniture did not match up with the school children's anthropometric measures on an average. So, most of the time they have to spent in the classroom sitting for a long duration at a time confining themselves to traditional cumbersome sitting and writing furniture units (Chakrabarti et al., 2004). Therefore, furniture induced postural problems associated with behavioral misfit become very common.

Mismatch between students anthropometric dimensions and their school desk and chair is believed to be at the grassroots of many problems encountered by pupils in and outside school settings. Literature on the issue pinpoints the following consequences: back pain prevalence among children and adolescents (Balague et al.; 1999; Trevelyan \& Legg, 2006), musculoskeletal discomfort and low back pain (Whittfield et al., 2001; Murphy, 2003; Trevelyan \& Legg, 2003), biomechanical, circulatory and visual problems (Ray et al., 1995); awkward postures adopted for extended periods of time affect academic performance (Oxford, 1969). While furniture design is seen as the prime factor affecting pupil's posture at school, other factors are just as important as furniture design and student anthropometric dimensions, like school organization (i.e.: time scheduling), different educational tasks (attending to the teacher, writing, drawing, reading on desk tops or even in the absence of a chair and desk). Studies have shown that being confined in awkward posture for specific task demand at a given situation or as influenced by bad designed furniture for a long duration provokes psychological stress and imposes ill effects on human performance (Das et al., 2004). There are numerous medical problems that have resulted because of the use of school furniture that do not match the anthropometry of the school children. Wrongly designed school furniture induces improper posture leading to operational uneasiness and musculoskeletal and some physiological disorders among school children (Mououdi \& Choobineh, 1997; Chaudhary et al., 2004). Long sitting hours in these improperly designed chairs may cause health hazards in the younger generation hampering their other physical activities. In the present investigation, efforts are made to acquire body dimension of the boys in rural schools, which are useful for designing furniture and layout of the classroom.

\section{Proposed method}

The present study was carried out on schoolboys only. For that purpose, 10 rural schools of different zone in Odeda area of Odeda local government in Ogun state Nigeria were selected, randomly.

Table 1

Classification of schoolchildren on the basis of their age and class

\begin{tabular}{ll}
\hline Age & Class \\
\hline 12 years & J.S.S $1^{*}$ \\
13 years & J.S.S 2* \\
14 years & J.S.S $3^{*}$ \\
15 years & S.S.S $1^{* *}$ \\
16 years & S.S.S $2^{* *}$ \\
17 years & S.S.S $3^{* *}$ \\
\hline
\end{tabular}

*Junior Secondary School

** Senior Secondary School 
Six hundred twenty one (621) schoolboys (between 12 and 17 years of age) from different schools were selected at random for the present study. The total numbers of subjects were classified into six major groups on the basis of their age (Table 1).

\subsection{Anthropometric measurement of body dimensions}

Different anthropometric measures of the school children were taken by adopting proper landmark definitions and standard measuring techniques (Singh \& Bhasin, 1989; Weiner \& Lourie, 1969; Ermakova et al., 1985; Chakrabarti, 1997). All the body dimensions of the children were taken only from the right side of their body. The equipments used for that purpose was an anthrop meter (Holtain), venire caliper - Range $0-68 \mathrm{~cm}$ with error $0.1 \mathrm{~mm}$ and metal tape. Accuracy and repeatability of measurement was achieved by practice prior to the data collection sessions. The data recorded for a subject was the mean of three trials.

All subjects were wearing light clothes and were bare footed during measurements. During measuring body dimensions under sitting condition, the subjects were asked to sit in such a way that the upper leg and lower leg remained at right angle to each other. The following anthropometric dimensions were taken for this study:

\subsubsection{Shoulder height, sitting}

Subject sat erect on a seat. Head in the Frankfort plane, upper arms hanging relaxed, forearms and hands were placed horizontally forming the right angles with the upper arms. The vertical distance from the seat surface to the shoulder was measured with an anthropometer. The measuring rule of the anthropometer was placed on the acromial end of the right clavicle.

\subsubsection{Infrascapulare height, sitting}

The vertical distance from the seat surface to the most prominent part of the lower portion of the right infrascapulare bone was measured by a shortened anthropometer. Subject sat erect on a seat. The arms were pressed against the trunk. The forearms were placed horizontally forming the right angles with the upper arms.

\subsubsection{Lower lumbar (5th) height, sitting}

The most prominent part of the upper portion of the right in-nominate bone was extended to the back of the subject to get the $5^{\text {th }}$ lumbar vertebral point. The vertical distance from the seat surface to that point was measured by a shortened anthropometer. Sitting position of the subject was the same as during the measurement of the sitting infrascapulare height.

\subsubsection{Popliteal height, sitting}

Subject sat erect on a seat, feet on the adjustable platform; knees flexed 90 degrees, and thighs parallel. With an anthropometer, the vertical distance from the floor to the lateral underside of the right thigh at a point contiguous to where the tendon of the biceps femoris muscle joins the lower leg was measured.

\subsubsection{Elbow to elbow length (writing position), sitting}

Horizontal distance across the lateral surfaces of the elbows (when the children used to write on the desk), spreading sideways was measured by a shortened anthropometer.

\subsubsection{Hip breadth, sitting}

The horizontal distance between the maximum bulges on the soft tissues in the hip area on either side is measured during sitting condition of the subject by a shortened anthropometer.

\subsubsection{Bi-deltoid breadth, sitting}

Subject sat erect on an adjustable seat where the arms were pressed against the trunk. The forearms were placed horizontally forming right angles with the upper arms. The maximum horizontal distance 
between the deltoid ale on either side was measured by a shortened anthropometer during sitting condition of the subject.

\subsubsection{Buttock-popliteal length, sitting}

Subject was asked to sit erect on an adjustable seat with knees flexed $90^{\circ}$ and thighs parallel. With the anthropometer, the horizontal distance from the most posterior aspect of the right buttock to the posterior surface of the right knee was measured.

\subsubsection{Elbow height from the floor, sitting}

Subject sat erect on an adjustable seat where the arms were pressed against the trunk. The forearms were placed horizontally forming right angles with the upper arms. The vertical distance from the seat to the olecranon of the right hand was measured with a shortened anthropometer. The measured value was then added with popliteal height of the same subject to get elbow height from the floor (sitting).

\subsubsection{Knee height, sitting}

The vertical distance from the floor to the point on the anterior surface of the distal part of the thigh which projects furthest upward (but not on the upper edge of the patella) was measured with an anthropometer. Sitting condition of the subject was the same as during the measurement of popliteal height.

\subsubsection{Thigh clearance height sitting}

The vertical distance from the seat surface to the maximum bulge on the anterior surface of the thigh was measured with a shortened anthropometer. Sitting condition of the subject was the same as during the measurement of the popliteal height.

\subsubsection{Buttock-feet length, sitting}

It is the maximum distance from the buttock to the acropodion of the children. The acropodion is usually on the big toe and less frequently on the adjacent or middle toe. The thigh and shin were at right angles to each other and it was measured against a scale.

\subsubsection{Foot length, sitting}

The projection of the distance between acropodion and pternion. Acropodion can be on the big toe, usually on the adjacent toe or on the middle toe and it was measured by a sliding caliper.

\subsubsection{Buttock-knee length, sitting}

Subject was asked to sit erect as stated in case of measuring buttock-popliteal length. With the anthropometer, held parallel to the long axis of the thigh, the horizontal distance from the most posterior aspect of the right buttock to the most anterior aspect of the right knee was measured.

\subsubsection{Elbow breadth, sitting}

A sliding caliper measured the horizontal distance between the two most prominent points on the right elbow joint. Subject sat erect on an adjustable seat. The upper arms were pressed against the trunk. The forearms were placed horizontally and form right angles with the upper arms and the palms were directed inward.

\section{Results and discussion}

\subsection{Anthropometric survey}

There are enormous variations in body size among individuals. The body dimension should match with furniture, equipment etc in a workstation. On the other hand, any mismatch in the work environment leads to users' discomfort, low productivity, work hazards, and accidents. Therefore, it can be said that body dimensions of children are important for the design of furniture, particularly which are used in schools. This possesses problems because children of different body sizes may be combined in the same classroom. Thus, desks and benches of very different sizes should be made available to fit different children. This is often difficult to do for a variety of organizational reasons. 
Provision of adjustable benches and desks, for example, might appear a suitable solution, but especially young children might have great difficulties in adjusting that furniture to their size and liking (Corlett et al., 1986). Moreover, adjustable seats and desks are costlier than the ordinary one. The most of the Indian schools situated in rural and semi-urban areas are unable to provide such furniture because of financial reasons. Therefore, it will be suitable to make fixed design of school furniture considering the anthropometric data of school children.

Table 2

Mean \pm S.D and range of different anthropometric dimensions of schoolboys with age different group

\begin{tabular}{lllllll}
\hline $\begin{array}{l}\text { Anthropometric } \\
\text { Dimension }(\mathrm{cm})\end{array}$ & $\begin{array}{l}\text { 12years } \\
(\mathrm{n}=106)\end{array}$ & $\begin{array}{l}\text { 13years } \\
(\mathrm{n}=105)\end{array}$ & $\begin{array}{l}\text { 14years } \\
(\mathrm{n}=104)\end{array}$ & $\begin{array}{l}\text { 15years } \\
(\mathrm{n}=103)\end{array}$ & $\begin{array}{l}16 \text { years } \\
(\mathrm{n}=102)\end{array}$ & $\begin{array}{l}\text { 17years } \\
(\mathrm{n}=101)\end{array}$ \\
\hline Shoulder height Sitting & $42.2 \pm 2.7$ & $44.8 \pm 3.4$ & $47.0 \pm 3.4$ & $49.9 \pm 3.9$ & $50.9 \pm 3.1$ & $53.7 \pm 3.7$ \\
Infrascapulare Height, sitting & $31.9 \pm 2.4$ & $33.7 \pm 3.1$ & $35.0 \pm 2.8$ & $30.5 \pm 4.0$ & $38.9 \pm 3.3$ & $40.8 \pm 3.2$ \\
Lower lumbar Height, sitting & $17.0 \pm 1.7$ & $18.5 \pm 1.6$ & $19.2 \pm 1.8$ & $21.1 \pm 2.4$ & $22.6 \pm 2.2$ & $23.8 \pm 1.5$ \\
Popliteal height, sitting & $33.9 \pm 2.2$ & $35.7 \pm 2.5$ & $37.6 \pm 2.3$ & $40.6 \pm 3.7$ & $42.7 \pm 3.5$ & $44.0 \pm 3.1$ \\
Buttock-popliteal length, sitting & $35.3 \pm 2.7$ & $38.3 \pm 2.5$ & $40.6 \pm 2.8$ & $44.0 \pm 4.5$ & $45.9 \pm 3.8$ & $46.7 \pm 2.8$ \\
Buttock-knee length, sitting & $42.7 \pm 3.1$ & $46.3 \pm 3.5$ & $49.5 \pm 3.5$ & $52.8 \pm 4.4$ & $53.8 \pm 6.7$ & $54.6 \pm 3.2$ \\
Buttock -feet length, sitting & $54.1 \pm 2.0$ & $57.9 \pm 2.8$ & $61.6 \pm 3.3$ & $62.6 \pm 3.9$ & $65.2 \pm 3.5$ & $68.0 \pm 4.2$ \\
Elbow height, sitting & $55.0 \pm 2.2$ & $57.2 \pm 2.4$ & $59.5 \pm 2.3$ & $61.1 \pm 2.3$ & $63.6 \pm 2.1$ & $64.4 \pm 2.2$ \\
Elbow breadth, sitting & $5.2 \pm 0.4$ & $5.6 \pm 1.1$ & $5.8 \pm 0.6$ & $6.3 \pm 0.7$ & $6.8 \pm 0.7$ & $7.0 \pm 0.7$ \\
Elbow-Elbow length (writing & $40.5 \pm 6.2$ & $41.9 \pm 4.9$ & $43.4 \pm 7.2$ & $45.7 \pm 6.5$ & $46.4 \pm 5.5$ & $47.9 \pm 7.5$ \\
position),Sitting & & & & & & \\
Knee height, sitting & $41.3 \pm 2.3$ & $42.5 \pm 2.2$ & $45.0 \pm 2.7$ & $46.2 \pm 2.4$ & $48.9 \pm 2.3$ & $50.7 \pm 2.4$ \\
Foot length, sitting & $18.6 \pm 1.2$ & $19.2 \pm 1.5$ & $20.2 \pm 2.0$ & $21.0 \pm 1.5$ & $22.5 \pm 1.5$ & $23.1 \pm 1.0$ \\
Thigh clearance height form seat, sitting & $9.9 \pm 0.8$ & $10.6 \pm 1.3$ & $11.2 \pm 1.3$ & $12.2 \pm 0.7$ & $13.5 \pm 0.9$ & $14.1 \pm 1.1$ \\
Hip breadth, sitting. & $21.8 \pm 1.6$ & $23.2 \pm 1.9$ & $24.7 \pm 2.2$ & $27.0 \pm 3.2$ & $28.9 \pm 2.1$ & $29.5 \pm 1.9$ \\
Bi-deltoid breadth & $31.2 \pm 2.3$ & $33.0 \pm 2.6$ & $34.7 \pm 3.0$ & $37.8 \pm 4.3$ & $38.3 \pm 3.0$ & $40.3 \pm 3.1$ \\
\hline
\end{tabular}

Table 2 presents different anthropometric dimensions related to classroom furniture and layout design. Results reflect that all anthropometric dimensions of the school children increase as their age increases. With the increase of age, development of skeletal system, muscular system, and other systems of the body occurs, and as a resultant, effect anthropometric measures increase. Therefore, it may be said that furniture of the same size will not fit the body dimension of the children of all age groups. The results indicate the need for separate design of furniture for different age groups.

In designing for a known individual, one's own body dimensions may be measured and used. However, for mass application the percentile values of a study population are usually required. A $95^{\text {th }}$ percentile value of a body dimension (e.g., body height) would indicate that $95 \%$ of the study population have the same or less body height, and only the remaining $5 \%$ of the population have greater heights. The $50^{\text {th }}$ percentile value represents closely the average, which divides the whole study population into two equal halves. As a matter of fact, no such person really exists, having all the body dimensions of $95^{\text {th }}$ or $50^{\text {th }}$ or $5^{\text {th }}$ percentiles. Therefore, for design application, different percentile values of different dimensions may be necessary even on a simple design solution. Based on task requirement, appropriate percentile selection of body dimensions is required.

Lower percentile values are considered for accommodating the maximum number of people having higher values, where easy reach is the concern. Higher percentile values are considered where the maximum number of population having lower values cannot reach the level, as required in ensuring safety and ease of operation (Nag, 1996). In the present investigation, various percentile values (5th, 50th and 95th) of different anthropometric dimensions of the school children of different age groups are computed for the purpose of designing school furniture and layout of the classroom which are presented in different tables.

Table 3 shows mean differences (\%) of anthropometric dimensions between the schoolboys of 12 and 13 years. It is observed from this table that differences between mean values of various 
anthropometric dimensions of schoolboys of 12 years and 13 years are very small (only 2.9\% to 8.8\%). It indicates that there is no massive change in body growth of the school children in this small age group. The changes are as little as $0.4-3.8 \mathrm{~cm}$ for all body measures. Therefore, the boys of two age groups are merged together and may be considered as a single group while selecting design dimensions for the school furniture. The percentile values of the anthropometric dimensions of the merged age group (12-13 years) are shown in Table 3. Similarly the mean differences (\%) of different anthropometric dimensions of the boys between 14 and 15 years are very small (1.3\% to 9.9\%) and the mean differences (\%) in case of 16 and 17 years vary from only $1.4 \%$ to $5.5 \%$.

Table 3

Percentile values of different anthropometric dimensions of schoolboys between 12-13 years of age.

\begin{tabular}{|c|c|c|c|c|c|c|c|c|}
\hline Anthropometric dimensions (cm) & $\begin{array}{l}\text { 12years } \\
(\mathrm{n}=106)\end{array}$ & $\begin{array}{l}\text { 13years } \\
(\mathrm{n}=105)\end{array}$ & $\begin{array}{l}\text { Mean } \\
\text { differences(\%) }\end{array}$ & $\mathrm{G}_{\text {mean }}$ & $\mathrm{G}_{\mathrm{S} . \mathrm{D}}$ & $\begin{array}{l}5^{\text {th }} \\
\text { \%ile }\end{array}$ & $\begin{array}{l}50^{\text {th }} \\
\% \text { ile }\end{array}$ & $\begin{array}{l}95^{\text {th }} \\
\% \text { ile }\end{array}$ \\
\hline Shoulder height, sitting & $42.2 \pm 2.7$ & $44.8 \pm 3.4$ & 6.2 & 43.5 & 3.3 & 38.1 & 43.5 & 48.9 \\
\hline Infrascapulare height, sitting & $31.9 \pm 2.4$ & $33.7 \pm 3.1$ & 5.6 & 32.8 & 2.9 & 28.0 & 32.8 & 37.6 \\
\hline Lower lumber $\left(5^{\text {th }}\right)$ height, sitting & $17.0 \pm 1.7$ & $18.5 \pm 1.6$ & 8.8 & 17.7 & 1.8 & 14.7 & 17.7 & 20.7 \\
\hline Popliteal height, sitting & $33.9 \pm 2.2$ & $35.7 \pm 2.5$ & 5.3 & 34.8 & 2.5 & 30.7 & 34.8 & 38.9 \\
\hline Buttock-popliteal length, sitting & $35.3 \pm 2.7$ & $38.3 \pm 2.8$ & 8.5 & 36.8 & 3.1 & 31.7 & 36.8 & 41.9 \\
\hline Buttock-knee length, sitting & $42.7 \pm 3.1$ & $46.3 \pm 3.5$ & 8.4 & 44.5 & 3.8 & 38.2 & 44.5 & 50.8 \\
\hline Buttock-feet length, sitting & $54.1 \pm 2.0$ & $57.9 \pm 2.8$ & 7.0 & 56.0 & 3.1 & 50.9 & 56.0 & 61.1 \\
\hline Elbow height, sitting & $55.4 \pm 2.2$ & $57.2 \pm 2.4$ & 3.2 & 56.3 & 2.5 & 52.2 & 56.3 & 60.4 \\
\hline Elbow breadth, sitting & $5.2 \pm 0.4$ & $5.6 \pm 1.1$ & 7.7 & 5.4 & 0.9 & 3.9 & 5.4 & 6.9 \\
\hline Elbow-Elbow length, sitting & $40.5 \pm 6.2$ & $41.9 \pm 4.9$ & 3.5 & 41.2 & 5.6 & 32.0 & 41.2 & 50.4 \\
\hline Knee height, sitting & $41.3 \pm 2.3$ & $42.5 \pm 2.2$ & 2.9 & 41.9 & 2.3 & 38.1 & 41.9 & 45.7 \\
\hline Foot length, sitting & $18.6 \pm 1.2$ & $19.2 \pm 1.5$ & 3.2 & 18.9 & 1.4 & 16.6 & 18.9 & 21.2 \\
\hline Thigh clearance, sitting & $9.9 \pm 0.8$ & $10.6 \pm 1.3$ & 7.1 & 10.2 & 1.1 & 8.4 & 10.2 & 12.0 \\
\hline Hip breadth, sitting & $21.8 \pm 1.6$ & $23.2 \pm 1.9$ & 6.4 & 22.5 & 1.9 & 19.4 & 22.5 & 25.6 \\
\hline Bi-deltoid breadth, sitting & $31.2 \pm 2.3$ & $33.0 \pm 2.6$ & 5.8 & 32.0 & 2.6 & 27.8 & 32.1 & 36.4 \\
\hline
\end{tabular}

Those two pairs of neighboring age groups are also treated as two single groups (14-15 years and 1617 years) and their percentile values body dimensions were computed which are shown in Table 4 and Table 5, respectively. On the other hand, the mean differences of body dimension are appreciably large $(16.2 \%$ to $42.2 \%)$ when they are compared between the boys of 12 years and 17 years. Therefore, design for single group (12-17 years) will not be suitable for matching user body dimension and furniture dimension. So, it is suggested to formulate furniture design for three different small age groups.

\section{Table 4}

Percentile values of different anthropometric dimensions of schoolboys between 14-15years of age

\begin{tabular}{|c|c|c|c|c|c|c|c|c|}
\hline Anthropometric dimensions (cm) & $\begin{array}{l}\text { 14years } \\
(n=104)\end{array}$ & $\begin{array}{l}\text { 15years } \\
(n=103)\end{array}$ & $\begin{array}{l}\text { Mean } \\
\text { differences(\%) }\end{array}$ & $\mathrm{G}_{\text {mean }}$ & $\mathrm{G}_{\mathrm{S} . \mathrm{D}}$ & $\begin{array}{l}5^{\text {th }} \\
\text { \%ile }\end{array}$ & $\begin{array}{l}50^{\text {th }} \\
\% \text { ile }\end{array}$ & $\begin{array}{l}95^{\text {th }} \\
\% \text { ile }\end{array}$ \\
\hline Shoulder height, sitting & $47.0 \pm 3.4$ & $49.9 \pm 3.9$ & 6.2 & 48.4 & 3.9 & 42.0 & 48.4 & 54.8 \\
\hline Infrascapulare height, sitting & $3.5 \pm 2.8$ & $38.3 \pm 4.0$ & 9.4 & 36.6 & 3.8 & 30.0 & 36.5 & 42.9 \\
\hline Lower lumber $\left(5^{\text {th }}\right)$ height, sitting & $19.2 \pm 1.8$ & $21.1 \pm 2.4$ & 9.9 & 20.1 & 2.3 & 16.3 & 20.1 & 23.9 \\
\hline Popliteal height, sitting & $37.6 \pm 2.3$ & $40.6 \pm 3.7$ & 8.0 & 39.1 & 3.4 & 33.5 & 39.1 & 44.7 \\
\hline Buttock-popliteal length, sitting & $40.6 \pm 2.8$ & $44.0 \pm 4.5$ & 8.4 & 42.3 & 4.1 & 35.6 & 42.3 & 49.0 \\
\hline Buttock-knee length, sitting & $49.5 \pm 3.5$ & $52.8 \pm 4.4$ & 6.7 & 51.1 & 4.3 & 44.0 & 51.1 & 58.2 \\
\hline Buttock-feet length sitting & $61.8 \pm 3.3$ & $62.6 \pm 3.9$ & 1.3 & 62.2 & 3.6 & 56.3 & 62.2 & 68.1 \\
\hline Elbow height, sitting & $59.5 \pm 2.3$ & $61.1 \pm 2.3$ & 2.7 & 60.3 & 2.4 & 56.4 & 60.3 & 64.2 \\
\hline Elbow breadth, sitting & $5.8 \pm 0.6$ & $6.3 \pm 0.7$ & 8.6 & 6.0 & 0.7 & 4.8 & 6.0 & 2.2 \\
\hline Elbow-Elbow length, sitting & $43.4 \pm 7.2$ & $45.7 \pm 6.5$ & 5.3 & 44.5 & 7.0 & 33.0 & 44.5 & 56.0 \\
\hline Knee height, sitting & $45.0 \pm 2.7$ & $46.2 \pm 2.4$ & 2.7 & 45.6 & 2.6 & 41.3 & 45.6 & 49.9 \\
\hline Foot length, sitting & $20.2 \pm 2.0$ & $21.0 \pm 1.5$ & 4.0 & 20.6 & 1.8 & 17.6 & 20.6 & 23.6 \\
\hline Thigh clearance, sitting & $11.2 \pm 1.3$ & $12.3 \pm 0.7$ & 9.8 & 11.7 & 1.2 & 9.7 & 11.7 & 13.7 \\
\hline Hip breadth, sitting & $24.7 \pm 3.2$ & $27.0 \pm 3.2$ & 9.3 & 25.8 & 2.9 & 21.0 & 25.8 & 30.6 \\
\hline Bi-deltoid breadth, sitting & $34.7 \pm 3.0$ & $37.8 \pm 4.3$ & 8.9 & 36.2 & 4.0 & 29.6 & 36.2 & 42.8 \\
\hline
\end{tabular}


Table 5

Percentile values of different anthropometric dimensions of schoolboys between 12-13years of age

\begin{tabular}{|c|c|c|c|c|c|c|c|c|}
\hline Anthropometric dimensions (cm) & $\begin{array}{l}\text { 16years } \\
(\mathrm{n}=102)\end{array}$ & $\begin{array}{l}\text { 17years } \\
(\mathrm{n}=101)\end{array}$ & $\begin{array}{l}\text { Mean } \\
\text { differences(\%) }\end{array}$ & $\mathrm{G}_{\text {mean }}$ & $\begin{array}{l}\text { S.D } \\
\pm \\
\end{array}$ & $5^{\text {th }} \%$ ile & $\begin{array}{l}50^{\text {th }} \\
\% \text { ile }\end{array}$ & $\begin{array}{l}95^{\text {th }} \% \\
\text { ile }\end{array}$ \\
\hline Shoulder height, sitting & $50.9 \pm 3.1$ & $53.7 \pm 3.7$ & 5.5 & 52.3 & 3.7 & 46.2 & 52.3 & 58.4 \\
\hline Infrascapulare height, sitting & $38.9 \pm 3.3$ & $40.8 \pm 3.2$ & 4.9 & 39.8 & 3.4 & 34.2 & 39.8 & 45.4 \\
\hline Lower lumber, $\left(5^{\text {th }}\right)$ height sitting & $22.6 \pm 2.2$ & $23.8 \pm 1.5$ & 5.3 & 23.2 & 2.0 & 19.9 & 23.2 & 26.5 \\
\hline Popliteal height, sitting & 42.73 .5 & $44.0 \pm 3.1$ & 3.0 & 43.3 & 3.4 & 37.7 & 43.7 & 48.9 \\
\hline Buttock-popliteal length, sitting & $45.9 \pm 3.8$ & $46.7 \pm 2.8$ & 1.7 & 46.3 & 3.4 & 40.7 & 46.3 & 51.9 \\
\hline Buttock-knee length, sitting & $53.8 \pm 5.7$ & $54.6 \pm 3.2$ & 1.8 & 54.2 & 4.6 & 46.6 & 54.2 & 61.8 \\
\hline Buttock-feet length, sitting & $65.2 \pm 3.5$ & $68.0 \pm 3.2$ & 4.3 & 66.6 & 4.1 & 59.9 & 65.6 & 73.3 \\
\hline Elbow height, sitting & $63.6 \pm 2.1$ & $64.4 \pm 2.2$ & 1.4 & 64.0 & 2.2 & 60.4 & 64.0 & 67.6 \\
\hline Elbow breadth, sitting & $6.8 \pm 0.7$ & $7.0 \pm 0.7$ & 2.9 & 6.9 & 0.7 & 5.7 & 6.9 & 8.1 \\
\hline Elbow-Elbow length, sitting & $46.4 \pm 5.4$ & $47.7 \pm 9.5$ & 3.2 & 47.1 & 6.6 & 36.2 & 47.1 & 88.0 \\
\hline Knee height, sitting & $48.9 \pm 2.3$ & $50.7 \pm 2.4$ & 3.7 & 44.8 & 2.5 & 45.7 & 49.8 & 53.9 \\
\hline Foot length, sitting & $22.5 \pm 1.5$ & $23.1 \pm 1.0$ & 2.7 & 22.8 & 1.3 & 26.7 & 22.8 & 24.9 \\
\hline Thigh clearance, sitting & $13.5 \pm 0.9$ & $14.1 \pm 1.1$ & 4.4 & 13.8 & 1.0 & 12.2 & 13.8 & 15.4 \\
\hline Hip breadth, sitting & $28.9 \pm 2.1$ & $29.5 \pm 1.9$ & 2.1 & 29.2 & 2.1 & 25.7 & 29.2 & 32.7 \\
\hline Bi-deltoid breadth, sitting & $38.3 \pm 3.0$ & $40.3 \pm 3.1$ & 5.2 & 39.3 & 3.2 & 34.0 & 39.3 & 44.6 \\
\hline
\end{tabular}

Different percentile values of anthropometric dimensions of schoolboys of different age groups (Present study) are compared (in Table 6) with the data as obtained from the work of Chakrabarti et al. (2004). For this purpose, different percentile values (5th and 95th) of different anthropometric dimensions of two combined age groups (12-13 years, and 14-15 years) have been computed. Note that data obtained from the present study are more or less the same (or a little difference) with the data as obtained from the study of Chakrabarti et al. (2004). These investigators collected data from the subjects of eastern part of India. The present investigation has also been conducted in the places, which are the parts of eastern India. This may be one of the possible reasons for a little difference (3.2\% to 7.7\%) between the data as obtained from the present study and the data obtained from the work of Chakrabarti et al. (2004). During designing of school furniture, various aspects of human comfort must be considered to make it suitable for the user. Therefore, consideration of different anthropometric dimensions of the school children is essential during determination of dimensions of classroom furniture. The anthropometric database of the present investigation may be helpful for designing of school furniture for the boys' schools in rural areas of Nigeria.

\section{Table 6}

Comparison of percentile values of different anthropometric dimensions of school boys between the present study and other study

\begin{tabular}{llllllcc}
\hline & & \multicolumn{5}{c}{ Age group } \\
\cline { 3 - 8 } \begin{tabular}{l} 
Anthropometric \\
\cline { 3 - 8 } dimension (cm)
\end{tabular} & \%ile & Present study & Other study* & Diff (\%) & Present study & Other study* & Diff (\%) \\
\hline Lower lumber height & 05 & 16.0 & 15.9 & 0.6 & 17.8 & 16.5 & 7.3 \\
Buttock-Popliteal length & 05 & 34.8 & 33.7 & 3.2 & 37.8 & 39.0 & 3.2 \\
Thigh Clearance & 95 & 13.0 & 14.2 & 9.2 & 14.2 & 15.3 & 7.7 \\
Buttock-knee length & 95 & 53.6 & 52.3 & 2.4 & 61.7 & 57.7 & 6.5 \\
\hline
\end{tabular}

*Chakrabarti et al. (2004)

The important dimensions of the furniture and the relevant user dimensions are shown Table 7. The upper surface height of the seat (bench) corresponds to the popliteal height of the population is under consideration (Sane et al., 2004). Other investigators (Molenbroek et al., 2003; Chakrabarti and Das, 2004), also hold the same opinion. On the other hand, the width of the seat may be determined from the hip width of the user during sitting condition (Molenbroek et al., 2003; Sane et al., 2004). So, data of sitting hip breadth obtained from the present investigation may be used for the determination of width of a single user seat. However, it should be more comfortable for the user if the length of the seat (bench) is determined by considering their sitting bi-deltoid breadth, in case of multiple users' seat. The data of the same collected from the present investigation will serve the purpose. Buttock- 
popliteal length (sitting) is helpful for the determination of depth of the seat (Chakrabarti \& Das, 2004). For the determination of table height investigators (Molenbroek et al., 2003) used the data of sitting elbow height of the user. So, data of sitting elbow height from the floor collected from the present investigation may be used for the determination of height of the working surface (desk) for seated children. Kroemer and Grandjean (2001) express that if we consider the measurement 'groundto-upper surface of knee' and make certain additions to allow for heels and for a minimum amount of movement, we will get the space for free knee room. Therefore, it can be said that the dimension of sitting knee height of the present investigation will be helpful for the determination of free knee room under the desk. It may be mentioned that the thigh clearance height from seat (sitting) should be used for the determination of vertical span for the accommodation of thighs between the bench top and underside of the desk. Molenbroek et al. (2003) also used thigh clearance sitting for the determination of vertical span below table. Buttock-feet length, sitting may be used for the determination of horizontal clearance below the desk. To determine tabletop length shoulder width of the user has been used by some workers (Sane et al., 2004). The said length determined from shoulder width may be suitable for a single user table. However, in case of multiple user-desks, the length calculated from the elbow-to-elbow length in writing position may be more suitable. Height for the upper point of the back support was also determined from the height of the lowest point of scapula (Molenbroek et al., 2003). In the present investigation sitting infrascapulare height was measured which will be helpful for the determination of the upper edge height of the backrest from the bench surface. In addition, the backrest must be capable of supporting the entire width of the back as well as to provide support for the lower back, i.e., lumber vertebrae (Sane et al., 2004). Chakrabarti and Das (2004) considered lower lumber height from seat for determining the lowest point height of the back support. The sitting lower lumber (5th) height collected from the present investigation may be used for determining the lower edge height of the backrest from the bench surface. This is also suggested by Chakroboti and Das (2004).

Maximum horizontal distance between the calf and the thigh (standing position) may be used for determining horizontal clearance for standing between the bench and the desk (in case of joined furniture unit). Foot length may be used for the determination of horizontal distance between the two front legs of a bench and two hind legs of a desk (in case of joined wooden furniture containing a four legged desk and a four legged bench). Buttock-knee length (sitting) may be helpful for the assessment of horizontal space below the desk for accommodating the knees of the users. Width of upper surfaces of armrests (in case of single seated chair/ bench) may be determined from the sitting elbow breadth. Maximum transverse diameter of the body may be helpful for the determination of minimal dimension required for passageways in the classroom, which may be helpful for designing classroom layout. While making school furniture the anthropometric dimension of the user should be used. The physical dimension should be settled from the suitable user's body dimension. Some important anthropometric dimensions and their applications are summarized in Table 7.

\section{Table 7}

The relevant dimensions in anthropometric design of school furniture

\begin{tabular}{|c|c|}
\hline User-dimensions & Product-dimensions \\
\hline Popliteal height, sitting & Upper surface height of the bench \\
\hline Bi-deltoid breadth, sitting & Length of the bench (in case of multiple users) \\
\hline Buttock-popliteal length, sitting & Depth of the bench \\
\hline Elbow height from the floor, sitting & Height of the desk \\
\hline Knee height, sitting & Free knee room under the desk \\
\hline Thigh clearance height from seat, sitting & $\begin{array}{l}\text { Vertical span for the accommodation of thighs between the } \\
\text { bench top and underside of the desk }\end{array}$ \\
\hline Buttock-feet length, sitting & Horizontal clearance below the desk \\
\hline Elbow to elbow length (writing position), sitting & Length of the desk \\
\hline Infrascapulare height, sitting & Upper edge height of the backrest from the bench surface \\
\hline Lower lumbar (5th) height, sitting & Lower edge height of the backrest from the bench surface \\
\hline
\end{tabular}




\section{Conclusion}

From the present study it may suggested that the design criteria should be selected for three age groups (12-13 years, 14-15 years and 16-17 years) in a secondary school. Otherwise, there are chances for misfit between the school furniture and the students. The ill designed furniture of the schoolchildren have created many problems for students such as fatigue, muscular stress, and pain/discomfort in their different body part. The improper design of classroom layout also has caused various problems of the children and their free movement in the classroom may be obstructed. The anthropometric database of the present investigation may be helpful for designing school furniture and layout design of the classroom for the boys' schools in rural areas in Nigeria. For co-education schools (for both boys and girls) separate database should be constructed because anthropometric measures of boys and girls differ.

\section{References}

Adejuyigbe, S.B \& Ali, D.M. (2004). Ergonomic evaluation of furniture in higher institution in Nigeria, A case study of FUTA. Nigerian Journal of Industrial and System Studies (NJISS), 3(1), 24-30.

Castellucci, H. I., Arezes, P. M., \& Viviani, C. A. (2010). Mismatch between classroom furniture and anthropometric measures in Chilean schools. Applied Ergonomics, 41(4), 563-568.

Chakrabarti, D. (1997). Indian anthropometric dimensions for ergonomic design practice, National Institute of Design.

Chakrabarti, D. \& Das, A. (2004). Design development of a new seat-desk unit suitable for Indian school children. Proceedings of National Conference on Humanizing Work and Work Environment, National Institute of Industrial Engineering.

Chaudhary, N., Sharma, D., Grover, R. \& Nainwal, U. (2004). Mismatch between classroom furniture dimensions and student anthropometric characteristics: A study of schools of Pantnagar. Proceedings of National Conference on Humanizing Work and Work Environment, National Institute of Industrial Engineering.

Corlett, N., Wilson, J., \& Manenica, I. (1986). The ergonomics of working postures: models, methods and cases. Taylor \& Francis, London, 21-29.

Das, A., \& Chakrabarti, D. (2004). Role of free postural adoption on performance and informal workplace design. Proceedings of National Conference on Humanizing Work and Work Environment, National Institute of Industrial Engineering, April, Mumbai.

Ermakova, S. V., Podstavkina, T. P., \& Strokina, A. N. (1985). Anthropometric Atlas, Recommendations on Methods. Amerind Publishing Co. Pvt. Ltd., New Delhi, 23-123.

Gouvali, M.K. \& Boudolos, K. (2006). Match between school furniture dimensions and children's anthropometry. Applied Ergonomics, 37(6), 765-773.

Hira, D.S. (1980). An ergonomic appraisal of educational desks. Ergonomics, 23, 213-221.

Indian Council of Medical Research (1989). Growth and physical development of Indian infants and children. New Delhi, 18, 1-176.

Ismaila, S. O. (2009). Anthropometric data of hand, foot, ear of university students in Nigeria. Leonard Journal of Sciences, 15, 15-20.

Jeong, B. Y. \& Park, K. S. (1990). Sex differences in anthropometry for school furniture design. Ergonomics, 33, 1511-1521.

Kroemer, K. H. E. and Grandjean, E. (2001). Fitting the task to the human: A text book of occupational ergonomics. Taylor and Francis, London.

Mououdi, M. A., \& Choobineh, A. R. (1997). Static anthropometric characteristics of students age range six-11 in Mazandaran province/Iran and school furniture design based on ergonomics principles. Applied Ergonomics, 28(2), 145-147

Molenbroek, J. F. M., Kroon-Ramaekers, Y. M. T. \& Snijders, C. J. (2003). Revision of the design of a standard for the dimensions of school furniture. Ergonomics, 46, 681-694.

Nag, P. K. (1996). Ergonomics and work design. New Age International (P) Limited, New Delhi, 129-154. 
Savanur, C. S., Ghosh, S., Dhar, U., \& De, A. (2004). An ergonomic study of comparison between school classroom furniture and student's anthropometry. Proceedings of National Conference on Humanizing Work and Work Environment, National Institute of Industrial Engineering.

Singh, I. P. \& Bhasin, M.K. (1989). Anthropometry. Kamla-Raj Enterprises, Delhi.

Sane, S. M., Karandikar, V., \& Savale, P. (2004). Ergonomic product design: classroom bench. Proceedings of National Conference on Humanizing Work and Work Environment, National Institute of Industrial Engineering.

Trevelyan, F. C., \& Legg, S. J. (2006). Back pain in school children-Where to from here? Applied Ergonomics, 37(1), 45-54.

Weiner, J. S. \& Lourie, J. A. (1969). Human biology: A guide to field methods, IBP Hand Book No.9. Blackwell Scientific Publications, Oxford. 